\title{
OBITUARY
}

\section{Christian George Albertyn}

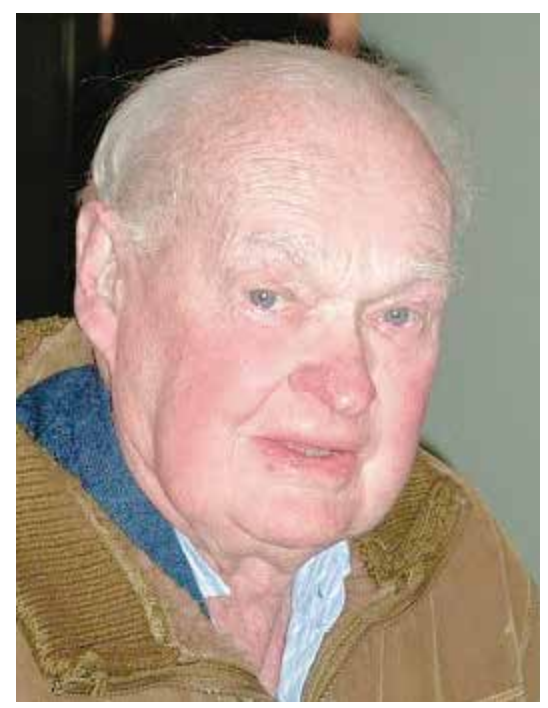

Christian George Albertyn was born on 13 December 1920 in Bethal, Transvaal. He started studying medicine at the University of the Witwatersrand in 1939. His studies were interrupted by World War II, and he joined up in 1941 and served in Egypt and Italy. He returned home in 1945, graduated in 1949, and did his internship at Edenvale Hospital.

George worked as a general practitioner in Vereeniging until 1966, when he started to specialise in radiology at the University of Pretoria, qualifying in 1969. He worked as a radiologist in private practice until he retired at the age of 65 , and then continued to work as a radiologist at Steve Biko Academic Hospital, where he was involved in teaching registrars, until the age of 75 . During his career as a radiologist he served as President of the Radiological Society.
George had a wonderful memory, and until the month before he died, despite his virtual blindness, he kept up to date with events and read avidly using his Merlin magnifier. He could do complex mathematical calculations in his head, and remembered the names of people he had met in his childhood and every telephone number he had ever had in his long life. If anyone wanted to know something from the past, George would invariably supply the answer. He adapted to new inventions, taking to the computer and later his iPad with alacrity, and could learn new languages with ease. He spoke English, Afrikaans and Dutch fluently, and picked up some isiZulu, Italian and Greek. He did cryptic crosswords every day until the day before he died.

A keen sportsman, George swam for Natal, captained the Wits university water polo team, and played tennis into his 70 s and golf until the age of 90. He loved rugby and cricket and continued to take an interest in these sports until his death.

George was an enthusiastic man. He loved his music, mostly jazz from the 1930s and 1940s, he loved to read, he loved learning about new things, and he always enjoyed stories and hearing about things other people were doing. He loved the game reserve and going on holiday with his family, he loved the sea and surfed until he could no longer manage the beach, he loved to bake and cook, he loved to teach, he loved to entertain, he loved travelling, and he adored his wife, children, grandchildren and greatgrandchildren. He was a tolerant and stoical man, and never liked to show that he was in pain or discomfort. He had a wonderful sense of humour and loved to laugh. He had enormous energy and zest for life, especially revealed by his interest in other people. He listened with focused attention, genuinely interested in their stories, and his politeness and respectful attention to others, whatever their age or station in life, was a wonderful example to everyone he encountered.

George was not one-dimensional; he may have been cheerful company when entertaining friends, but he was also a methodical and careful professional and parent. He was blessed with the talent to use his energy astutely and effectively, achieving many things in his long life on a very wide front.

As a medical doctor, George sometimes had the sad task of helping families over their grief at the passing of a loved one. He was a district surgeon at Sharpeville after the shootings, a bitter and terrible experience for a war veteran. This could have made a lesser man become cynical, but he knew and acted upon the knowledge that ultimately everyone is responsible for their own happiness.

George used his close relationships to express his life and dreams. He and his wife Helen, also a radiologist, had a remarkable and exemplary marriage. Helen was his companion, guiding star, great passion and support. He had four children, ten grandchildren and two great-grandchildren, and had a special relationship with them all.

George Albertyn has left us a rich and brilliantly lit path and example. He took hold of life with both hands and shared his journey with us all. He died peacefully in his sleep on 20 March 2014.

\section{Lynda Albertyn-Cross}

Child, Adolescent and Family Unit, Charlotte Maxeke Johannesburg Academic Hospital, Johannesburg, South Africa

drlcross@telkomsa.net 